\title{
O separacji między prawem i moralnością. Glosa do Czystej teorii prawa Hansa Kelsena
}

Marta Huk (Uniwersytet im. Adama Mickiewicza)

\section{Porządek normatywny}

W swej normatywistycznej koncepcji rozwijanej w Czystej teorii prawa (1934, 1960) Hans Kelsen przyjmuje metodologiczne założenia dynamicznej teorii prawa, która zakłada konieczność hierarchizacji norm w obrębie konkretnego systemu po to, aby można było wykazać prawomocność każdej z nich zarówno jako racji działania prawnego, jak i podstawy orzekania $w$ procesie, także powiązanej z kwalifikacją działania jako prawnego bądź nieprawnego. Oznacza to, że pełna analiza normatywizmu jako takiego nie może ograniczać się do rekonstrukcji podstawowych założeń normy, lecz musi także uwzględnić metody (i rezultaty) różnych rodzajów wzajemnego powiązania norm. Początkowo Kelsen nie dostrzegał tego problemu. Kwestię porządku prawnego (czyli systemu norm) podejmie dopiero w późniejszym okresie twórczości, zdając sobie sprawę z faktu, iż metoda statyczna, w której obowiązywanie prawa wynika ze stanowionych treści i ich wzajemnych powiązań, nie daje pełnego i poprawnego oglądu normatywizmu, czyli nie spełnia podstawowego założenia metodologii prawoznawczej, którym jest wymóg opisywania prawa takim, jakie ono jest w rzeczywistości. Pod wpływem koncepcji Merkela Kelsen poprawił ten błąd metodologiczny i w efekcie czytelnik Czystej teorii prawa zapoznać się może z komparatystyką porządku społecznego i prawnego, pod kątem systemu normatywnego o charakterze dynamicznym, czyli takim, w którym porządek prawny obowiązuje na mocy własnej struktury (Zalewska 2014, 46).

Kelsen wyróżnia wiele systemów normatywnych, jednak powodem, dla którego dokonuje szczegółowej analizy porządku społecznego, administracji państwowej i systemu prawnego jest ich zbliżona struktura, opierająca się na sankcjonowaniu zachowań niepożądanych. Założenia obu porządków są zbliżone z uwagi na pełnioną przez nie rolę, jaką jest danie legitymizacji do działania lub zaniechania działania. Podstawową funkcją normatywizmu jest bowiem nałożenie niezależnych od jednostkowych przekonań standardów, na gruncie których istnieje racja do nakazywania, zakazywania lub upoważniania (Brożek et al. 2013, 21). Innymi słowy, normatywność może być traktowana jako czynnik schematycznie (formalnie) regulujący sferę powinności. Można stąd wyprowadzić wniosek, że system normatywny jest zbiorem wszystkich i tylko tych reguł, które stanowią zewnętrzną rację do wykonania lub 
zaniechania określonego zachowania. Celem każdego porządku normatywnego jest wypracowanie pożądanych zachowań jednostek. Normatywizm w ujęciu Kelsenowskim zorientowany jest zarówno epistemologicznie, co oznacza, że jego główną osią metodologiczną jest analiza kryteriów działania i sądzenia oraz ich wzajemnych relacji, jak i ontologicznie - analizuje istotę bytów normatywnych i powinności (Brożek et al. 2013, 20-21), jednak nie uzurpuje sobie przy tym prawa do konstruowania sądów subiektywnie-wartościujących.

\subsection{Porządek społeczny}

Za porządek społeczny (social order) w teorii prawa Hansa Kelsena należy uznać najszerszy system normatywny, w ramach którego występują porządki wyróżnione, odrębne i w dużej mierze - choć nie zawsze pełnej - autonomiczne, takie, jak: porządek moralny, religijny, prawny, zespół norm kulturowych etc. Jest on definiowany jest dwojako, tj. w odniesieniu do podmiotów i przedmiotów resp. stanów rzeczy, ponieważ na gruncie koncepcji Kelsena:

Zachowanie jednostki może, lecz nie musi pozostawać w relacji do innych jednostek: człowiek może zachowywać się w konkretny sposób względu na innego człowieka, a także zwierzęta, rośliny i inne nienazwane byty (Kelsen 1970, 24).

Przewrotność tej myśli nie zakłada to jednak absolutnego braku relacyjności zachowań, wręcz przeciwnie - Kelsen dzieli relacje na bezpośrednie (gdy zachowanie X-a implikuje określone zachowanie Y-a) oraz pośrednie (gdy zachowanie X-a wywołuje pewne konsekwencje, pod wpływem których Y zachowuje się $\mathrm{w}$ określony sposób). Zatem porządek społeczny może być określany jako rezultat relacji zachowania jednego podmiotu do zachowania innego lub jako porządek normatywny, który reguluje zachowania ludzi w bezpośredniej lub pośredniej relacji do innych ludzi. Jednak niezależnie od przyjmowanej definicji, cel porządku społecznego pozostaje niezmienny wypracowanie zachowań jednostek podległych danemu porządkowi. Kelsen zaznacza, że społeczną motywacją pożądanych zachowań jest funkcja nakazywania lub zakazywania określonych postaw podmiotów podległych danemu porządkowi społecznemu ${ }^{1}$. Przełożenie tego stwierdzenia na język czystej teorii skutkuje tezą głoszącą, że każdy człowiek zobligowany jest przez daną normę lub zespół norm do określonego zachowania lub zaniechania zachowania. Innymi słowy, system norm społecznych wyznacza zakres akceptowalnych zachowań jednostki względem porządku społecznego poprzez bezpośrednie lub pośrednie relacje między zachowaniami (Jelić 2001, 561562). Kelsen zaznacza jednak, że logika normatywizmu jest silniejsza niż funkcje społeczne systemu. Oznacza to, że każde zachowanie człowieka

1 Funkcja motywacyjna porządku społecznego rozpatrywana jest tu z perspektywy psychologiczno-socjologicznej. 
regulowane jest nie w stosunku do innego człowieka², lecz w stosunku do wymogów systemu samego w sobie. Powstaje jednak pytanie o to, w jaki sposób porządek społeczny wywołuje wśród jednostek pożądane zachowania.

Porządek społeczny egzekwowany jest z kolei za pomocą sankcji. Nie oznacza to jednak, że sankcje społeczne funkcjonują na tej samej zasadzie, co sankcje prawne ${ }^{3}$. Kelsen zastanawia się, czy do pomyślenia jest w ogóle jakikolwiek porządek społeczny, który obowiązywałby - i rzeczywiście efektywnie zobowiązywałby - bez konieczności wprowadzania sankcji. Swoje założenia wyprowadza z przykładu porzucenia reguły retrybucji w Nowym Testamencie. Na podstawie przytaczanych przez niego cytatów z Biblii wynika, że porzucenie sankcji w postaci kary zostało automatycznie uzupełnione przez sankcje rozumiane jako nagrody: nawet $w$ porządku religijnym, który w zachodnioeuropejskim paradygmacie jest pośrednio przekładalny na porządek moralny, istnieje nadrzędna sankcja, którą dla chrześcijan jest Niebo ${ }^{4}$, czyli w domyśle zbawienie i życie wieczne. Dowodzi to założenia o konieczności występowania sankcji właściwie w każdym porządku normatywnym (Kelsen 1970, 27). Ich charakterystyczną odmianą jest sankcja moralna. Autor dochodzi do wniosku, że jest to jedyny typ sankcji, który opiera się wyłącznie na opozycji aprobata - dezaprobata. Zachowanie nakazane na gruncie porządku moralnego jest społecznie aprobowane, podczas gdy zachowanie zabronione spotyka się $\mathrm{z}$ dezaprobatą, zatem ten, kto postępuje według norm moralnych jest uznawany za osobę moralną, a ten, kto je pogwałca, uchodzi za osobę niemoralną, która musi być (moralnie) napiętnowana. Otóż okazuje się, że także w tym charakterystycznym systemie aprobata bądź dezaprobata członków społeczeństwa jest tożsama z karą lub nagrodą, czyli - sankcją. Kelsen dokonuje podziału sankcji na transcedentalne i immanentne społecznie. Stanowią one narzędzie egzekucji dla różnych porządków normatywnych, lecz jako sankcje dążą do tego samego celu, jakim jest wywołanie pożądanego zachowania.

Sankcją transcendentalną (transcendental sanction) nazywa się sankcję zgodną $\mathrm{z}$ przekonaniami podmiotów podległych porządkowi ustanowionemu przez najwyższy, nadludzki autorytet (superhuman authority) - jest to narzędzie charakterystyczne dla porządków o charakterze religijnym. Z kolei o sankcjach społecznie immanentnych (socially immanent sanctions) autor mówi jako o faktycznych, mających miejsce w obrębie rzeczywistości społecznej (resp. naturalnej) i wykonywanych przez członków tegoż społeczeństwa w stosunku do innych jego członków. Do tej grupy zalicza między innymi sankcje prawne i moralne. Należy wspomnieć, że zgodnie

2 Autor podkreśla, że żaden człowiek nie myśli „w stosunku” do drugiego człowieka. 3 Przykładem może być porządek moralny, który według Kelsena, historycznie nie posiada żadnych sankcji, a mimo to potrafi skutecznie egzekwować pożądane zachowania.

4 Prywatnie Kelsen był zwolennikiem sekularyzmu - przykład Nieba jedynie wyostrza jego stanowisko. 
z takim rozumieniem sankcji, dla Kelsena nawet natura przybiera postać quasinormatywną: jest ona społecznie interpretowanym porządkiem, łączącym konkretne zachowania z konkretnymi sankcjami 5 .

Jednak sankcja na gruncie ogólnie rozumianego porządku społecznego ma szersze znaczenie niż w porządku prawnym: jest ona bowiem każdą konsekwencją deliktu, co oznacza, że może nią być zarówno kara, jak i nagroda. Takie rozumienie sankcji narzuca dwie zasadnicze różnice interpretacyjne między porządkiem społecznym oraz, wyróżnionym w nim, porządkiem prawnym. Po pierwsze, sankcja rozumiana jako nagroda lub kara modyfikuje definicję zachowania nakazanego. Po drugie, umożliwia ona jednoczesne funkcjonowanie norm, będących wzajemnie sprzecznymi (Green 2003, 368).

Zachowanie nakazane (commanded behavior) jest, na gruncie porządku społecznego, przeciwieństwem zachowania będącego warunkiem sankcji, która powinna być egzekwowana (Kelsen 1970, 25). Wprowadzenie owej definicji, należącej do kategorii negatywnych, prowadzi do interesujących konsekwencji: skoro dane zachowanie jest nakazane, oznacza to, że w przypadku zachowania przeciwnego sankcja powinna być nakazana. Innymi słowy, wykonanie sankcji jest nakazane wówczas, gdy jej warunkiem jest brak egzekucji ${ }^{6}$. Wynika stąd, że na gruncie porządku społecznego wykonywanie sankcji może być w niektórych przypadkach upoważnieniem (np. porządek prawny):

Jeśli $\mathrm{X}$ zachowa się $\mathrm{w}$ sposób $\mathrm{y}$, to określony organ $\mathrm{A}$ jest upoważniony do nałożenia na X sankcji S.

w innych zaś nakazem (np. porządek religijny):

Jeśli $\mathrm{X}$ zachowa się $\mathrm{w}$ sposób $\mathrm{y}$, to określony organ $\mathrm{A}$ jest zobligowany do nałożenia na X sankcji S.

Drugą konsekwencją takiego rozumienia pojęcia sankcji jest według Kelsena brak możliwości wzajemnego wykluczania się norm porządku społecznego. Autor uważa, że na gruncie tego samego porządku można znaleźć legitymizację dla zachowań przeciwnych, co znaczy, że w obrębie jednego systemu na gruncie normy A zachowanie $\mathrm{x}$ jest zabronione, lecz $\mathrm{w}$ obrębie innego systemu na gruncie normy $\mathrm{B}$ to samo zachowanie $\mathrm{x}$ jest nakazane. Taka sytuacja jest możliwa oczywiście pod pewnymi warunkami: normy „powinno nastąpić x” oraz „nie powinno nastąpić $x$ " nie mogą być przestrzegane przez tę samą jednostkę w tym samym czasie, bowiem zakaz i nakaz nie mogą być jednocześnie respektowane na gruncie jednego i tego samego zachowania. Jednak te same normy wyrażone w formie „jeśli $A$, powinno nastąić $x$ ” oraz "jeśli $\sim A$, powinno

5 Natura, rozumiana raczej jako specyficzny porządek społeczny, może łączyć zachowania z sankcjami na gruncie reguły kauzalności bądź retrybucji.

6 Skoro egzekucja sankcji jest upoważnieniem organu prawnego, to można powiedzieć, że w przypadku porządku społecznego innego niż porządek prawny, wykonanie sankcji jest nakazane wyłącznie w określonych okolicznościach. 
nastąić $x$ " nie wykluczają się wzajemnie (Kelsen 1970, 25), lecz mogą być ważne jednocześnie; dlatego w danej chwili sprawca działania może przeżywać np. dylemat prawno-moralny. Również w przypadku porządku prawnego byłaby to sytuacja logicznej sprzeczności, zwanej kontratypem. Jednak zarówno porządek społeczny jak i porządek prawny dopuszcza okoliczności, w których takie zestawienie - a raczej rozbieżność norm - jest akceptowalna. Mogą być one opisywane z wyłączeniem logicznej sprzeczności, jednak wciąż będą wyrazem możliwego konfliktu przekonań (conflicting political tendencies) - konfliktu teleologicznego. Niemniej jednak, pomimo niezadowalającego i kłopotliwego w praktyce podejmowania decyzji rezultatu, współistnienie takich norm jest możliwe (Patterson 1952, 7). W przypadku porządku prawnego jedna z wzajemnie wykluczających się norm byłaby automatycznie normą unieważnioną lub unieważniającą.

Ta pozornie zawiła i niejasna logicznie sytuacja mieści się w ramach prostej egzemplifikacji. Należy jednak przyjąć za Kelsenem następujące założenia:

1. porządek normatywny jest rodziną zbiorów wszystkich systemów podpadających pod jego definicję;

2. w ramach porządku społecznego mieszczą się inne, specjalistyczne porządki normatywne, takie jak porządek prawny lub moralny;

3. porządek funkcjonujący $w$ ramach porządku społecznego może, lecz nie musi pozostawać w relacji do innego porządku funkcjonującego w ramach porządku społecznego;

zatem norma porządku A może pozostać w sprzeczności z normą porządku B. Innymi słowy, jeśli na gruncie porządku moralnego dana norma głosi, że „jeśli $A$, powinno nastąpić $x^{\prime \prime}$, a inna norma na gruncie porządku prawnego głosi, że "jeśli $\sim A$, powinno nastapić $x$ ", to powyższe dwie normy mogą równocześnie funkcjonować niezależnie, na gruncie porządku społecznego. Oczywiście, w sytuacji, w której dane zachowanie jest upoważnione lub nakazane na gruncie jednego porządku i zakazane na gruncie drugiego, dochodzi do dylematu, którego Kelsen jednak nie rozwiązuje, ponieważ nie jest to już zagadnienie z zakresu czystej teorii prawa.

Powyższe rozważania stanowią jeden z filarów tezy o separacji prawa od moralności, będącej podstawą dla niniejszej analizy.

\subsection{Porządek prawny}

Koniecznym punktem wyjścia rozważań o celach i sposobach istnienia porządku prawnego jest zarysowanie podstawowych definicji, bez których nie sposób zrozumieć ideę prawnego normatywizmu. Spośród nasuwających się pytań, tym wyjściowym dla Kelsena zdaje się być pytanie o to, czym w istocie jest

7 Co oznacza, że normy, jako wzajemnie sprzeczne, nie mogą być jednocześnie ważne. 
prawo. Autor zdaje sobie sprawę z faktu, że językowe pojęcie prawa jest zbyt szerokie, aby mogło w sposób jednoznaczny i zadowalający zostać zdefiniowane. Jednak czysta teoria, z uwagi na swoje specyficzne podejście do nauk prawnych, może posługiwać się najogólniejszą definicją:

Kiedy porównamy przedmioty desygnowane przez pojęcie "prawo" przez różnych ludzi w różnych czasach, widzimy, że wszystkie te przedmioty okazują się być porządkami ludzkiego zachowania (Kelsen 1970, 31).

Porządek prawny, podobnie jak każdy porządek normatywny, jest systemem norm, których jedność konstytuowana jest przez fakt, że wszystkie mają te same podstawy ważności. Wówczas, na mocy tej definicji, pojedyncza norma jest ważna prawnie wtedy, gdy koresponduje $\mathrm{z}$ koncepcją prawa jako takiego ${ }^{8}$ oraz jest częścią porządku prawnego. Norma staje się zaś częścią porządku prawnego wyłącznie wtedy, gdy jej ważność oparta jest na jakiejś normie podstawowej dla tego systemu ${ }^{9}$.

Skoro czysta teoria aspiruje do miana nauki opisującej prawo takim, jakie jest $\mathrm{w}$ istocie, prawoznawstwo nie może posiłkować się badaniem odseparowanych od siebie norm, bez uprzedniego hierarchizowania i ustalania występujących między nimi zależności na gruncie jednolitego systemu. Należy jednak zastanowić się nad tym, jaką legitymizacją i jakimi warunkami obowiązywania powinien odznaczać się system prawa, który odpowiada założeniom normatywizmu (Zirk-Sadowski 2009, 55).

Prawo w koncepcji Kelsena funkcjonuje jako wymuszony porządek (coercive order), co oznacza, że pełni funkcję regulującą określone, niepożądane zachowania ${ }^{10}$ poprzez przymusowe czynności - sankcje. Upoważnienie danej jednostki do skierowania przymusowego działania przeciwko innej jednostce należy zatem rozpatrywać w kategorii wspomnianej już sankcji immanentnej społecznie. W tym miejscu warto odnotować pewną osobliwość czystej teorii, wedle której podmiot sam w sobie nie jest zobligowany na mocy prawa, lecz upoważniony do nałożenia na inną jednostkę wymuszonego działania nakazanego przez normę. Innymi słowy, nakazane jest jedynie to, co bezpośrednio czerpie swoje źródła $\mathrm{z}$ normy prawnej, czyli działanie wymuszone (coercive act) (Kelsen 1970, 33-35). Oczywiście, skutkuje to pożądaną przez Kelsena monopolizacją wzajemnej władzy wśród wspólnoty prawnej, która ma być gwarantem ładu prawnego i zbiorowego bezpieczeństwa obywateli, mogącego osiągać różne poziomy rozwojowe. Najogólniej rzecz ujmując, zbiorowe bezpieczeństwo jest to taki stan, w którym ochrona społeczeństwa osiąga minimalny stopień - bezpieczeństwo jest wówczas

8 Kelsen odwołuje się tutaj do najogólniejszej, pozytywistycznej definicji prawa.

$9 \mathrm{~W}$ przypadku czystej teorii, taką normę nazywa się Grundnorm.

10 Zachowania te uznawane są za niepożądane, z uwagi na ich szkodliwość społeczną. 
gwarantowane przez porządek prawny i funkcjonuje dalej jako szeroko rozumiany porządek społeczny (Green 2003, 376).

Porządek prawny na gruncie normatywizmu musi wobec tego spełniać dwa warunki: uporządkowania i obowiązywania. Uporządkowanie należy utożsamiać z jednej strony z hierarchiczną strukturą norm, a z drugiej - z dynamiczną koncepcją prawa. Z kolei kategoria obowiązywania jest u Kelsena znacznie bardziej skomplikowana. Wywodzi się ona ze specyficznego pojęcia istnienia normy. Skoro istnienie jest cechą bytu, czyli cechą należącą wyłącznie do sfery bytu, to musi ono znaleźć swój odpowiednik w sferze powinności. Czysta teoria prawa uważa właśnie obowiązywanie porządku normatywnego (prawnego) za ekwiwalent istnienia bytu (Zalewska 2014, 46-47). Owo obowiązywanie jest ściśle uzależnione od tego, czy norma, której dotyczy, znajduje swoją legitymizację w akcie prawnym - czyli, czy została ona w sposób ważny i wiążący wydana. Zatem uzasadnienie obowiązywania normy prawnej może przebiegać dwutorowo: z jednej strony zawiera się w ustanowionej $\mathrm{w}$ normie powinności, a $\mathrm{z}$ drugiej zaś jest wynikiem wskazania normy hierarchicznie wyższej w danym porządku prawnym (Wróblewski 1966, 160).

Jednak aby pojęcie obowiązywania mogło być w ogóle skuteczne, musi istnieć pewne sprzężenie między zbiorem zachowań jednostek a regulującym je porządkiem normatywnym. Według Kelsena oznacza to, że każda norma prawna musi być przekraczalna, gdyż w przeciwnym wypadku byłaby nonsensem. Unormowanie twierdzenia, że „Ziemia jest planetą Układu Słonecznego" jest formalnie możliwe, jednak z zasady pozostaje prawnie bezwartościowe. Z kolei normowanie zachowań niewywierających żadnych negatywnych konsekwencji społecznych może okazać się zbytecznym aktem przekroczenia uprawnień organu prawodawczego (Kelsen 1970, 37-39).

Zatem aby porządek prawny mógł obowiązywać, musi on zawierać się między minimalną, a maksymalną wartością skuteczności ${ }^{11}$. Należy więc stwierdzić, że prawo obowiązuje, ponieważ w przypadku przekroczenia przez obywatela dyspozycji normy państwo jest upoważnione do zareagowania aktem przymusowym.

\subsection{Struktura porządku moralnego}

Specyfika rozróżnienia porządków normatywnych na prawny i moralny polega według Kelsena przede wszystkim na konsekwentnym wyznaczeniu granicy normowalnych zachowań. Po pierwsze, rozróżnienie nie odnosi się do tych zachowań, które mogą być jednocześnie normowane na gruncie obu powyższych porządków społecznych. Innymi słowy, te zachowania, które są

11 Kelsen nie sprowadza pojęcia obowiązywania do skuteczności, ponieważ według niego, skuteczność jest przymiotem bytu, a nie powinności, więc jako taka, nie może bezpośrednio warunkować użyteczności systemu normatywnego rozpatrywanego wyłącznie w kategoriach powinności. 
nakazane, zakazane lub upoważnione na gruncie prawa nie muszą mieć wyłącznie prawnego charakteru, czego przykładem może być obowiązujący na gruncie obu porządków zakaz zabijania - charakterystyka tej normy polega na możliwości jej jednoczesnego uzasadnienia na gruncie prawa i moralności, co jednak w żadnym wypadku nie oznacza, że uzasadnienia te mogą być tożsame ${ }^{12}$. Po drugie, Kelsen wskazuje poważny błąd, jakim jest twierdzenie, że normy porządku prawnego legitymizują zachowania w sferze zewnętrznej lub dzielonej z innymi ludźmi (external behavior), podczas gdy normy porządku moralnego - zachowania w sferze wewnętrznej, inteligibilnej, motywacyjnej (internal behavior). Twierdzeniem prawdziwym jest natomiast twierdzenie opozycyjne - zarówno normy prawne, jak i moralne określają zachowanie zewnętrzne i wewnętrzne. Oznacza to, że jeśli dany porządek prawny zakazuje zabójstwa, to zakazuje nie tylko odbierania życia innemu człowiekowi (aspekt zewnętrzny), lecz także nakazuje powstrzymać się od wszelkich działań a nawet zamiarów i zamysłów, które doprowadzają do odebrania życia innemu człowiekowi (aspekt wewnętrzny). Podobnie należy zatem strukturalizować argumentację na gruncie porządku moralnego - moralny zakaz zabójstwa dotyczy nie tylko zachowania zewnętrznego, jakim jest odebranie komuś życia, lecz także zachowania wewnętrznego, rozumianego tu nie jako powstrzymanie się od wypełniania znamion czynu zabronionego, lecz jako wewnętrznej legitymizacji działania niezgodnego ze skłonnościami lub egoistycznymi pobudkami jednostki (egoistical interest) (Kelsen 1970, 60). Zatem specyfika moralnego porządku normatywnego polega nie na legitymizowaniu wewnętrznych racji do działania, determinujących zachowania inne niż te, które normowane są przez porządek prawny, lecz na dążeniu do stworzenia systemu takich norm, które są ważne niezależnie od jednostkowych przekonań, pobudek czy skłonności. Na gruncie porządku społecznego, stanowienie norm niezgodnych ze skłonnościami, a nawet po prostu interesami i dobrami poszczególnych jednostek, jest zdaniem Kelsena nieuniknione. Należy je jednak uznać także za konieczne, a nawet pożądane, gdyż warunkują one obowiązywalność i skuteczność porządku społecznego, a także harmonijność życia publicznego (Zalewska 2011, 78-79) i pokój społeczny między różnymi mniejszościami społecznymi. Nie zmienia to jednak faktu, że na gruncie każdego porządku społecznego możliwy jest wewnętrzny konflikt skłonności jednostki - wówczas okazuje się, że podmiot wybiera to zachowanie, które jest dla niego silniej uwarunkowane, co znaczy, że podmiot reaguje zgodnie z tą skłonnością, która jest w danym momencie intensywniejsza. Konsekwencje, zarówno pozytywne, jak i negatywne społecznie, są zatem ocenianie z punktu widzenia konkretnego porządku moralnego (Vinx 2007, 70).

12 Nie należy zatem mieszać argumentacji prawnej z moralną - pomimo wypracowania tego samego narzędzia, jakim jest norma, porządki te nie mają takich samych roszczeń do uzasadniania powinności i zachowania. 
Abstrahując od poziomu jednostkowego, należy stwierdzić, że dla Kelsena sytuacją idealną $\mathrm{z}$ punktu widzenia etyki jest zachowanie przeciwstawiające się skłonnościom lub egoistycznym pobudkom, które zawsze ma wartość moralną (moral value). Ta ostatnia powinna być rozumiana jako racja do działania inna niż własne skłonności, przy jednoczesnym nieuświadamianiu sobie egoistycznych pobudek. Zatem okazuje się, że normy porządku moralnego odnoszą się jedynie do motywów zachowania. Implikuje to konieczność wypracowania przez inny porządek społeczny systemu zewnętrznych zachowań, adekwatnych do treści norm moralnych. W konsekwencji można przyjąć, że taki porządek moralny nie jest sam w sobie porządkiem zupełnym. Jego obowiązywalność musi być zatem wynikiem sprzężenia normy moralnej odnoszącej się do samego podmiotu z inną normą moralną, która nakazuje zachowanie zewnętrzne. Innymi słowy, zupełny porządek moralny to porządek, w którym jedne normy określają zachowanie podmiotu względem „wewnętrznego" samego siebie, a inne - względem „zewnętrznego" społeczeństwa. Zatem zachowanie można uznać za moralne dopiero wtedy, gdy spełnia przynajmniej dwa warunki; po pierwsze, jest wynikiem normy odnoszącej się do motywów zachowania oraz po drugie i najważniejsze - zachowanie samo w sobie odpowiada konkretnej normie moralnej (Kelsen 1970, 61-62).

Przyjęta struktura porządku normatywnego z grubsza odpowiada pewnym założeniom Immanuela Kanta. Filozof twierdził, że działanie ma wartość moralną, jeśli wypływa z zastosowania się do obowiązku, ale nie w sposób ślepy i bezmyślny, lecz autonomiczny, poddany procedurze uniwersalizacji na mocy imperatywu kategorycznego, tj. podniesieniu do rangi powszechnie akceptowalnej przez rozumne istoty racji działania. Przezwyciężenie indywidualnych skłonności i pozadeontologicznych pobudek działania na rzecz obowiązku umożliwia wewnętrzne zobowiązanie jednostki do podjęcia określonych działań (por. Kant 2009, 11-23) poprzez wzbudzenie u niej rozumnie ugruntowanego szacunku dla obowiązku, wyrażonego określonym prawem moralnym lub inną zasadą, o ile spełnia ona opisane kryterium uniwersalizowalności (Guyer 2010, 130-151). Ostatecznie, Kelsen silnie akcentuje różnicę między porządkiem moralnym i prawnym. Analizując porządek moralny, wyprowadza dwa wnioski, które okażą się kluczowe dla pełnego zrozumienia tezy o separacji prawa i moralności. Autor wykazuje, że porządek moralny $\mathrm{w}$ przeciwieństwie do prawnego jest porządkiem niewymuszonym (co pozostaje w zgodzie z Kantem) oraz, że wartość moralna jest wartością względną (co już nie jest wnioskiem zgodnym z założeniami Kanta).

Na gruncie czystej teorii prawa, różnica między porządkiem prawa i moralności nie wyczerpuje się w sposobie tworzenia i stosowania norm. Według Kelsena, normy moralne, podobnie jak prawne - czego jednak sam nie bierze w swych badaniach pod uwagę, powstają zwyczajowo oraz kreowane są 
poprzez akty wolitywne. Oznacza to, że zarówno porządek prawny (co zostało już wcześniej wykazane) jak i porządek moralny są $\mathrm{w}$ pewnym sensie porządkami pozytywnymi, bowiem niezależnie od sposobu regulacji, zawsze odnoszą się do zachowania.

Pomimo, iż porządek moralny nie wymaga zbudowania administracyjnej struktury władzy, jego roszczenie do ważności skutkuje wytworzeniem się obowiązków. Specyfika obowiązywania tego porządku normatywnego polega na tym, że aplikacja normy zawiera w sposób immanentny moralną ewaluację zachowań innych podmiotów, która regulowana jest na gruncie zasad tegoż porządku (Kelsen 1970,62). Kelsen zaznacza jednak, że powyższe twierdzenie argumentuje na rzecz tezy o separacji jedynie w przypadku rozwiniętych systemów prawnych ${ }^{13}$. Zatem oś rozróżnienia powyższych porządków nie powinna przebiegać wokół przedmiotu, który jest przez nie normowany (tj. sposobów zachowań), lecz wokół sposobu normowania. Innymi słowy, różnica między prawem, a moralnością ma polegać na tym, w jaki sposób normy nakazują, zakazują lub upoważniają określone zachowania.

Fundamentalną różnicę między prawem a moralnością należy wywodzić z faktu, że prawo jest ze swojej natury porządkiem wymuszonym, czyli takim, w którym normatywna regulacja zachowań zachodzi poprzez dodanie do zachowania przeciwnego do pożądanego, społecznie zorganizowanego aktu (socially organized act) - sankcji, podczas gdy porządek moralny jest tych ostatnich pozbawiony ${ }^{14}$. Zatem budowa norm obu porządków powinna wyglądać następująco:

1. Norma porządku prawnego:

Jeśli $\mathrm{X}$ dopuści się czynu zabronionego $\mathrm{y}$, to określony organ A jest upoważniony do nałożenia na X sankcji S.

2. Norma porządku moralnego:

$\mathrm{X}$ nie powinien dopuszczać się czynu y, gdyż y jest moralnie naganny.

Jak już zostało wykazane, nie oznacza to jednak, że w przypadku porządku moralnego przekroczenie normy nie spotyka się z żadną karą. Moralność nakłada sankcje, jednak te ograniczają się jedynie do aprobaty lub dezaprobaty zachowania, jako zgodnego lub niezgodnego z normą. Nie sposób tu jednak

$13 \mathrm{~W}$ przeciwnym wypadku, tj. w przypadku decentralizacji ośrodka władzy, rozróżnienie uzasadniania obowiązywalności norm, z zachowaniem podziału na prawne i moralne, okazuje się być niewykonalne. Przykładem takiej decentralizacji może być struktura prawa międzynarodowego (w II poł. XX wieku), dlatego Kelsen twierdzi, że teoretycy prawa powinni raczej mówić o międzynarodowej moralności. 14 Kelsen ma tu na myśli sankcje zinstytucjonalizowane. Nie wyklucza on jednak istnienia innego rodzaju - tj. pozainstytucjonalnych, moralnych sankcji, np. wyrzutów sumienia, napiętnowania społecznego lub poczucia winy. 
mówić o sankcjach, rozumianych formalnie, jako stanowione akty przymusu (Kelsen 1970, 62). Zatem porządek ten ma w sposób szczególny, pozbawiony przymusu, normować zachowania, dążąc do nadania im wartości moralnej.

Należy zatem zadać sobie pytanie o to, w jaki sposób istnieją wartości moralne. Kelsen, podobnie jak inni pozytywiści, utrzymuje, że każde poznanie naukowe musi co najmniej powstrzymywać się od uznania, że istnieją jakiekolwiek, a w szczególności moralne wartości absolutne. Takie wartości istnieją jedynie w sferze dogmatów religijnych, na mocy absolutnego i transcendentnego autorytetu lub obiektywnego realizmu metafizycznego. Jednakże nie jest tu brana pod uwagę specyfika aksjologii, która w dużej mierze przypomina specyfikę sfery powinnościowej.

Przełożenie dogmatów religijnych na porządek moralny skutkowałoby koniecznością uznania wartości absolutnych (Smith 2003, 576-598) co w wielu przypadkach ma miejsce. Oznacza to, że religijna moralność ocenia zwykle dany czyn w każdym czasie i okolicznościach w sposób bezwzględny, czyli niezależnie od społecznego kontekstu, jego moralna ewaluacja byłaby niezmienna. Ten rodzaj moralności jest silnie zdogmatyzowany. Przyjęcie tego fałszywego założenia implikowałoby $w$ jej obrębie konieczność ustalenia niezmiennego opisu rzeczywistości powinności: jeśli na mocy jednego porządku moralnego, dane zachowanie uznawane jest za złe, to $\mathrm{w}$ innych okolicznościach, czasie i na mocy innego porządku moralnego zachowanie to również musiałoby być uznane za złe ${ }^{15}$. Ten sposób ujmowania moralności nie dopuszcza żadnego typu relatywizacji ani pluralizmu.

Społeczny stan rzeczy dotyczący wartości jest jednak z reguły inny od opisanego wyżej. W wielu społeczeństwach współczesnych występuje pluralizm i relatywizację porządków moralnych zależnie od okoliczności historycznych, socjologicznych, kulturowych etc., co oznacza, że możliwe jest, aby z perspektywy jednego porządku dany czyn był uważany za dobry, sprawiedliwy lub pożądany, podczas gdy na gruncie innego porządku uchodzić będzie za naganny lub pozbawiony wartościowości (neutralny aksjologicznie i normatywnie), co przesądza o względnym charakterze wartości moralnych (Kelsen 1970, 62-63). Zdaniem Kelsena, względność ta może pociągać za sobą także specyficzną redukcję: wyrażenie, że normy moralne muszą zawierać

15 Powstaje zatem pytanie, czy w przypadku uznania wartości absolutnych można mówić o pluralizmie porządków normatywnych - ich bezwzględność pociąga za sobą uznawanie wyłącznie jednej racji do działania, niezależnej od czasu i okoliczności, co oznacza, że każde zachowanie powinno być analizowane z perspektywy jednej i tej samej doktryny. Ponadto, uzasadnienie powinności na gruncie wartości absolutnych zaciera granice między poszczególnymi społecznymi porządkami normatywnymi, takimi jak prawo i moralność. Jeśli dany czyn jest bowiem zabroniony na mocy absolutnego autorytetu, to niezależnie od normatywnej legitymizacji, obowiązywanie i usankcjonowanie normy pozostaje niezmienne. Kelsen w Czystej teorii prawa nie podejmuje jednak tego problemu, skupiając się nie na obowiązywaniu formalnym, lecz treściowym wartości absolutnych. 
określoną treść, aby mogły być uznane za sprawiedliwe i postrzegane jako prawo sprowadza się do twierdzenia, że muszą one zawierać element wspólny dla wszystkich systemów sprawiedliwości, rozumianego jako częściowego, wspólnego mianownika. Kelsen dowodzi jednak, że taka redukcja nie musi mieć miejsca, gdyż niemożliwe jest wyróżnienie jednego, wspólnego dla wszystkich systemów elementu. Pluralizm porządków moralnych zakłada, że to, co stanowi wartość nadrzędną w obrębie jednego systemu, w innym ma wartość niższą, peryferyjną lub pozostaje indyferentne. Jednak nawet gdyby taki wspólny element istniał, i tak nie mógłby być dostatecznym uzasadnieniem dla usankcjonowania systemu moralnego. Innymi słowy, względność wartości moralnych, a co za tym idzie, także pluralizm porządków moralnych i wpisany $\mathrm{w}$ nie $\mathrm{z}$ racji wielości i różnorodności relatywizm, nie mogą być punktem odniesienia dla prawa. To zaś oznacza, że uzasadnienie zabronienia czynu jako „niemoralnego” lub „niesprawiedliwego” - jeśli nie zawiera odniesień do stosownych norm istniejącego prawa - nie jest warunkiem wystarczającym do usankcjonowania go, czyli ukonstytuowania w ramach normy prawnej (Kelsen 1970, 63-64; Halpin 2006).

Podsumowując tę część rozważań, odrzucenie absolutnej ważności wartości moralnych, która a priori determinowałaby dane zachowanie i czyniła zeń również a priori zachowanie dobre lub złe, moralne lub niemoralne, sprawiedliwe lub niesprawiedliwe, skutkować musi przyjęciem założenia o względności wartości moralnych. Implikuje to możliwość estymacji porządku wymuszonego, tj. prawa na gruncie systemu moralnego. Okazuje się bowiem, że każdy porządek prawny dzięki możliwości etycznej interpretacji jego norm podlega moralnej ocenie ${ }^{16}$. Tym, co wyróżnia normy moralne na tle innych porządków jest ich specyficzna właściwość polegająca na tym, że regulują one szeroko rozumiane (powinnościowe) zachowania podmiotów względem samych siebie oraz względem wszystkich innych członków społeczeństwa. Oznacza to, że mają one zdolność do wyróżniania pewnych zachowań jako pożądanych. Z kolei tym, co łączy ze sobą wszystkie normy moralne pozostaje ich forma:

Moralnie dobre jest to, co odpowiada opisującej konkretne zachowanie normie społecznej; moralnie złe jest to, co pozostaje w opozycji do takiej normy. Zatem relatywna wartość moralna jest ustanawiana przez normę społeczną regulującą sposób, w jaki

16 Warto zaznaczyć, że Kelsen opisując strukturę porządku moralnego posługuje się innymi kategoriami, niż w przypadku opisu porządku prawnego. Ma to służyć rozróżnieniu na prawo, które ma zdolność do samoistnej legitymizacji oraz moralność, która uzasadnia szerzej rozumiane fakty społeczne. Innymi słowy, moralność niejako porządkuje rzeczywistość społeczną za pomocą takich kategorii jako dobro, zło, sprawiedliwość etc., zatem jej zakres normowania może być znacznie szerszy niż zakres norm porządku prawnego. 
mają zachowywać się ludzie. Norma i wartość pozostają sprzężonymi kategoriami (Kelsen 1970, 65).

Z powyższego cytatu wynika zatem, że prawo znajduje moralne uzasadnienie nie dlatego, że posiada określoną treść poddającą się sądom ocennym (czynienie A lub zaniechanie B), lecz dlatego, że formalnie stanowi ono normę. Specyfika tej normy polega na sankcjonowaniu zachowań i powinności jako nakazanych, zakazanych lub upoważnionych, co oznacza, że jest ona względnie moralna. Uściślając, system prawa, jako porządek regulujący zachowania posiada względną wartość moralną, która nie jest zależna od treści norm. Zatem pytanie o związek prawa i moralności nie jest pytaniem o treść, lecz o strukturę. Prawo samo w sobie stanowi wartość wyłącznie z uwagi na fakt, że jest prawem. Wartość tę nazywa Kelsen wartością prawną (legal value), co oznacza jednak nic więcej ponad fakt, że prawo posiada względną wartość moralną (Kelsen 1970, 64-65). Nie determinuje to oczywiście etycznego charakteru danego porządku prawnego. Autor odrzuca tym samym założenie, jakoby prawo, aby mogło obowiązywać, musiało spełniać pewne moralne minimum. Wręcz przeciwnie wykazuje on konsekwentnie niezależność porządku prawnego od porządku moralnego, bowiem założenie o wewnętrznej moralności prawa implikowałoby jego zdaniem konieczność przyjęcia twierdzenia o ujednoliceniu treści moralnych prawa i, pośrednio, podporządkowania się założeniu o wartościach absolutnych.

Tymczasem moralne ideały o roszczeniu do uniwersalności, takie jak międzynarodowy pokój, są przez niego traktowane jako żądanie utworzenia systemu absolutnej moralności, wyrażanego poprzez wspólną dla wszystkich porządków moralnych treść (wspólny mianownik). Zatem minimum wartości prawnej oraz względność wartości moralnej nie tylko nie muszą pozostawać ze sobą we wzajemnej relacji, lecz - na poziomie formalnym - powinny być od siebie uniezależnione (Anderson 2010).

\section{Teza o separacji prawa i moralności}

Teza o separacji, zwana także $w$ literaturze tezą o rozdziale prawa i moralności, stanowi punkt kulminacyjny założenia o niezależności porządku prawnego od innych systemów normatywnych. Jej postać nie jest jednak tak silna, jak mogłoby się wydawać. Kelsen utrzymuje, że skoro prawo jest z zasady autonomiczne na każdym poziomie obowiązywania i uzasadniania, to błędem byłoby stwierdzenie, że czerpie ze źródeł zewnętrznych lub jest od nich w jakikolwiek sposób uzależnione, włącznie z innymi społecznymi systemami normatywnymi, spośród których, z perspektywy założeń czystej teorii, najważniejszy jest porządek moralny. Przyjęte przezeń uprzednio postulaty torowały drogę do sformułowania tezy o separacji, wyznaczając możliwe sposoby interpretacji i zewnętrznego uzasadniania obowiązywania nakładane na konkretny system prawa. 
Punktem wyjścia dla zaproponowania tezy o separacji jest wykazanie bezzasadności częstego $\mathrm{w}$ filozofii prawa poglądu o absolutnej wartości moralnej porządku prawnego, utożsamianej zwykle ze sprawiedliwością. Według Kelsena twierdzenie, że prawo jest „moralne”, wysuwane na gruncie założeń o wartościach absolutnych, pozostaje w sprzeczności względem powinności prawa do bycia moralnym (Kelsen 1970, 66). Innymi słowy, uznanie moralnego charakteru prawa wyklucza dyskusję nad tym, czy oraz $\mathrm{w}$ jaki sposób prawo powinno być moralne. Bowiem żądanie to znajduje swoje uzasadnienie jedynie wtedy, gdy przyjmie się możliwość istnienia niemoralnego lub nie w pełni moralnego systemu normatywnego jako prawa w jakimś (a niekiedy zupełnym) stopniu nagannego, moralnie złego. Pozytywizm prawniczy wprowadził rozróżnienie na żądanie rozgraniczenia prawa i moralności oraz prawa i sprawiedliwości, tj. wymóg nieutożsamiania ich ze sobą i rozgraniczania. Rozgraniczenie to zapobiega pokusie przyjęcia założenia o absolutnej wartości moralnej prawa, które to założenie jest zdaniem Kelsena błędne (Gardner 2001, 212-218).

Przyjęcie koncepcji zrelatywizowanych wartości moralnych umożliwia przeniesienie akcentu ze sfery bytu na sferę powinności, bowiem twierdzenie, że prawo powinno być moralne, to znaczy sprawiedliwe, oznacza jedynie tyle, że forma prawa pozytywnego powinna odpowiadać konkretnemu systemowi moralnemu, który zostaje wybrany spośród wielu różnych systemów(Kelsen 1970, 66-67):

Jeśli, przyjmując założenia relatywnej koncepcji wartości, wymagana się ogólnie rozumianej separacji prawa i moralności, a w szczególności prawa i sprawiedliwości, to wymaganie to nie oznacza, że porządek prawny i moralny lub prawo i sprawiedliwość są niepowiązane; nie oznacza to, że koncepcja prawa jest niezależna od koncepcji Dobra (Kelsen 1970, 66).

Kelsen dostrzega, że koncepcja aksjologii relatywnej jest często mylona z nihilistycznymi koncepcjami braku wartości moralnych jako takich lub relatywizowania ważności tych, które już się przyjęło, zależnie od sytuacji lub punktu widzenia. Dla Kelsena przyjęcie wspomnianego założenia pozwala jedynie uznać, że norma należąca do danego porządku prawnego może być pożądana lub niepożądana równolegle na gruncie różnych systemów wartości moralnych. Na przykład norma zakazująca rytualnego uboju zwierząt na gruncie jednego porządku moralnego uznawana jest za właściwą, pożądaną lub po prostu zasadną (także ze względu na zwyczaj), podczas gdy na gruncie innego porządku uchodzi za niepożądaną, krzywdzącą. To, co wydaje się rodzić dobro z perspektywy jednego systemu aksjologicznego, z perspektywy innego wydaje się rodzić zło. Oznacza to, że pojęcie dobra wywodzi się ze sfery powinności i jako powinność nie może być wyrażone inaczej niż za pomocą normy. Zatem jeśli prawo jest normą, to znaczy, że jego obowiązywanie jest niezależne od zewnętrznej ewaluacji oraz odpowiedniości lub 
nieodpowiedniości w stosunku do danego porządku moralnego (Paulson 1992, 15). Zadaniem moralności nie jest więc regulacja bądź też wyznaczanie zakresu normowania prawa, lecz dostarczenie określonego standardu ocennego.

Relatywistyczna teoria wartości, która umożliwia separację prawa i moralności oraz prawa i sprawiedliwości, prowadzi Kelsena do postawienia dwóch tez, istotnych z perspektywy czystej teorii prawa: po pierwsze, jeśli porządek prawny oceniany jest jako moralny lub niemoralny, sprawiedliwy lub niesprawiedliwy, to owe oceny wyrażają relację porządku prawnego do jednego z wielu możliwych systemów (moralnych), lecz przecież nie do jedynego systemu moralnego; przez co porządek ten konstytuuje jedynie relatywne, a nie absolutne sądy wartościujące. Po drugie, ważność pozytywnego porządku prawnego nie jest zależna od jego potwierdzalności na gruncie jakichś systemów moralnych. Powyższe z kolei prowadzi Kelsena do wniosku, że niemożliwe jest zaproponowanie absolutnego standardu ewaluacji (absolute standard of evaluation), gdyż jeden osąd nie może być uzasadniany w ten sam sposób na gruncie różnych systemów moralnych (Kelsen 1970, 67). Moralność powinna być zatem wykorzystywana jako narzędzie ocenne zgodne z założeniami relatywistycznej teorii wartości. Wówczas porządek prawny mierzony w skali wartości z zakresu jednego systemu moralnego może jawić się (na gruncie tego i tylko tego systemu) jako sprawiedliwy lub niesprawiedliwy (White 1996, 237). Należy jednak pamiętać o tym, że z perspektywy czystej teorii prawa norma prawna nie jest w żadnym wypadku zależna od moralności lub też jakkolwiek z nią powiązana, przez co może być uznana za ważną na gruncie naukowego poznania prawnego nawet wówczas, gdy nie jest zgodna (variance) z wybranym porządkiem moralnym.

Podsumowując, spełnienie tezy o separacji prawa i moralności możliwe jest wyłącznie na gruncie założeń o relatywistycznej teorii wartości. Ocena porządku prawnego jest zasadna tylko przy wykorzystaniu norm konkretnego systemu moralnego. Nie jest ona jednak wiążąca, co oznacza, że obowiązywalność prawa nie jest w żadnej mierze uzależniona od jego moralnej ewaluacji (Moser 1979, 102-105). Innymi słowy, moralność nie dostarcza legitymizacji prawu ani też nie wpływa na formę i treść poszczególnych jego norm. Niemniej jednak, ewaluacja i wynikające z niej uzasadnianie (moral justification) porządku prawnego na podstawie pojedynczego systemu moralnego jest, pod pewnymi warunkami, możliwe.

\subsection{Etyczne konsekwencje tezy o separacji z perspektywy relatywistycznej teorii wartości}

Abraham Edel, analizując stanowisko Iji Lazari-Pawłowskiej (Edel 1970, 584588), wykazał bezzasadność absolutnej teorii wartości, wystawiając ją na próbę dwóch pytań: „czy można stwierdzić, że dwoje ludzi kieruje się tymi samymi zasadami moralnymi, jeśli są one różnie usankcjonowane?” oraz „czy można mówić o dwóch identycznych kodeksach moralnych, jeśli posiadają one różne 
legitymizacje?”. Badacz doszedł do wniosku, że moralność jako całość to nie tylko teoretyczny system w ogóle, lecz także jego przyczyny i konsekwencje. Zatem, jeśli dana zasada powstanie na tle różnych okoliczności, mając sankcjonować różne zachowania, nie sposób mówić o jej bezwzględnej uniwersalności. Z kolei, rozpatrując konsekwencje przekroczenia pozornie identycznych norm moralnych, należy odwołać się do szerszego kontekstu społecznego. Lazari-Pawłowska twierdzi zaś, że pogwałcenie pewnej normy może w ramach jednego społeczeństwa może skutkować jedynie poczuciem winy u podmiotu, podczas gdy pośród innej społeczności sankcje mogą być znacznie dotkliwsze (Edel 1970, 587).

Kelsen, argumentując na rzecz relatywnej teorii wartości oraz pluralizmu systemów moralnych, wychodzi z podobnych założeń. Teza o separacji prawa i moralności jest zatem $\mathrm{z}$ jednej strony wymogiem zachowania czystości prawa, a $\mathrm{z}$ drugiej wynika ona $\mathrm{z}$ konieczności przeprowadzenia rozdziału między jednoznacznym prawem i jego kategoriami a nieostrymi kategoriami etyki, prawa naturalnego czy socjologii. Należy jednak podkreślić, że Kelsen nie odmawiał tym dyscyplinom naukowości. Zakładał on raczej brak ich bezpośredniego powiązania z metodologią czystej teorii prawa (White 1996, 234). Zatem z perspektywy etyki należy go klasyfikować jako przedstawiciela ograniczonego kognitywizmu17, a ściślej - jako zwolennika relatywistycznego sceptycyzmu co do absolutnej ważności aksjologicznej (Moser 1979, 111). Pogląd podobny do Kelsenowskiego prezentuje Gilbert Harman. Twierdzi on, że:

Z mojego punktu widzenia, osoba może dokonywać wewnętrznych osądów opartych na moralności indywidualnej, odnoszącej się wyłącznie do niej (...) Istnieje wiele przykładów moralności, według której dana osoba prezentuje standardy możliwe do zaakceptowania wyłącznie przez nią, czyli takie, które w żadnym wypadku nie mogą być aplikowane przez inne jednostki. (...) Istnienie takich przykładów jest potwierdzeniem tezy relatywistycznej (Harman 1975, 21-22).

Autor Czystej teorii prawa zakłada, że podejmując decyzje wyrażane w aktach normotwórczych społeczeństwo konstytuuje pewne wartości. Wartości te dla poszczególnych jednostek w danym społeczeństwie mogą być jednak diametralnie różne. Nie ma podstaw, by twierdzić, że jedne wartości są moralnie dobre, a inne złe; spory o wartości nie mają w tym kontekście sensu. Należałoby zatem przyjąć taki porządek obowiązywania, który zmuszałby jednostkę do przestrzegania prawa niezależnie od jej własnej, indywidualnej oceny etycznej tegoż prawa. Kelsen nie wyprowadza jednak tak ekstremalnych

17 Silnym argumentem na rzecz nieuznawania Kelsena za zwolennika nonkognitywizmu jest odrzucenie przez Autora stanowiska emotywizmu. Na gruncie czystej teorii istnieją pewne obiektywny standardy moralne, które mogą być poznawalne, lecz pozbawione są charakteru absolutnego. 
wniosków ze swojej koncepcji. Aby zrozumieć ocenną rolę moralności w społecznym porządku normatywnym, należy przedstawić jego stanowisko na rzecz prymatu stanowiska filozoficznego relatywizmu nad filozoficznym absolutyzmem.

Kelsen charakteryzuje filozoficzny absolutyzm jako metafizyczny pogląd głoszący, że istnieje pewna absolutna rzeczywistość, niezależna od wiedzy i nieograniczona czasem i przestrzenią. Taka rzeczywistość jest personifikowana i przedstawiana jako absolutna władza sprawiedliwego stwórcy, który włada światem i ustanawia wartości będące emanacjami rzeczywistości. Według tego systemu zasady moralne są niezmienniczymi opisami absolutnej rzeczywistości, które przejawiają się $\mathrm{w}$ ramach boskiego prawa naturalnego. Koncepcja ta nie dopuszcza zatem separacji poszczególnych porządków normatywnych, co z kolei oznaczałoby, że nie zachodzi tu rozdział między prawem a moralnością (Kelsen 1970, 27). Z kolei stanowisko filozoficznego relatywizmu odrzuca założenie o niezależności wartości na rzecz poszukiwania ich źródeł w życzeniach i obawach, a mówiąc precyzyjniej w preferencjach ludzkich (Kelsen 1970,198).

Kelsen, nie mogąc zaakceptować religijnej metafizyki, adaptował relatywistyczną i sceptyczną koncepcję etyki. Próbował wykazać bezzasadność poglądów, że relatywizm aksjologiczny jest niemoralny i nie przystaje do zasad moralnej odpowiedzialności podmiotowej: twierdzenie, że zasady moralne konstytuują jedynie relatywne wartości oznacza jedynie tyle, że człowiek ma wybór między kilkoma moralnymi systemami. Jednostka musi samodzielnie decydować o tym, co jest dobre, a co złe, i ów przymus odpowiedzialnego, pociągającego za sobą konsekwencje decydowania nakłada na nią ogromną odpowiedzialność także w kwestii przestrzegania prawa (Moser 1979, 112). Należy zauważyć, że Kelsen mówi tu o kilku, a nie o wielu systemach moralnych, co może sugerować, że ogranicza on wybór preferowanych wartości należących tylko do jednego z systemów, lecz jednocześnie wskazuje na dowolność wyboru jednostki. Z drugiej strony, liczebność systemów nie ma tutaj żadnego znaczenia.

W swoim etycznym stanowisku Kelsen podkreśla doniosłość przestrzegania rozdziału między systemem prawa i moralności. 0 ile bowiem ten drugi zakłada dowolność wyboru preferowanych wartości, o tyle pierwszy funkcjonuje na zasadzie przymusu. Z perspektywy etycznej złamanie prawa może być zatem motywowane działaniem zgodnym $\mathrm{z}$ wyznawanym przez jednostkę systemem wartości moralnych i gotowością przyjęcia adekwatnych do przewinienia sankcji; na tym m.in. opiera się nieposłuszeństwo obywatelskie. Na gruncie koncepcji Kelsena zasadność okaże więc np. pogląd, że przywiązanie człowieka do pewnych fundamentalnych sądów moralnych, niezależnie od ich źródła, tworzy podstawy radzenia sobie z moralnymi konfliktami, które można nazwać obiektywnymi. Okazuje się bowiem, że nawet 
relatywizm aksjologiczny czystej teorii prawa daje podstawy do uznania swoistej „etyczności” koncepcji prawa (Moser 1979, 113).

\subsection{Relacje prawa i moralności na gruncie normatywizmu}

Uznanie prawa i moralności za odrębne, metodologicznie ze sobą niepowiązane systemy norm rodzi pytanie o naturę relacji łączących prawo i moralność. $\mathrm{Na}$ gruncie podstawowego dualizmu Kelsen stwierdza, że pytanie to może być dwojako interpretowane: po pierwsze, może wskazywać na to, jaka jest rzeczywista relacja prawa do moralności oraz, po drugie - jaka relacja powinna łączyć te dwa porządki. Wzajemne utożsamianie tych pytań skutkuje według Autora szeregiem nieporozumień (Kelsen 1970, 62-63).

Odpowiedź na to pytanie jest zasadniczo oczywista. Powszechnie bowiem uważa się, że prawo jest w swojej istocie moralne, czyli, że zachowanie uchodzące $\mathrm{w}$ danym porządku społecznym za pożądane jest jednocześnie nakazane lub upoważnione zarówno przez prawo, jak i przez moralność. Jeśli z kolei prawo nakazuje zachowań społecznie niepożądanych, uważanych przez określony porządek moralny za złe, oznacza, że porządek prawny nie jest prawem, gdyż uchodzi za niesprawiedliwy (Tokarczyk 2009, 253; por. Radbruch 2009). Jednakże na mocy tezy o separacji Kelsen wykazuje, że związek prawa i moralności nie jest związkiem koniecznym; prawo może, lecz nie musi być moralne. Zatem porządek społeczny, który nie jest sprawiedliwy 18 , może być uznawany za prawo. Jednak odpowiedź na to samo pytanie, przedstawiona z perspektywy treści, nie zaś formy prawa okazuje się zupełnie inna. Kelsen twierdzi, że związek prawa z moralnością najsilniej zarysowany jest w aspekcie zawartości normy prawnej. Zakłada się bowiem, że norma jest w swojej istocie moralna, co znaczy, że ustanawia pewną konkretną moralną wartość, a w konsekwencji - jest sprawiedliwa (Kelsen 1970, 63). Dla odmiany, Radbruch formułuje rzecz w ten sposób, że prawo ma dążyć do tego, by umożliwiać realizację wartości moralnych, samemu pozostając wyłącznie prawem. Takie stwierdzenie byłoby jednak równoznaczne $\mathrm{z}$ uznaniem, że porządek prawny realizujący wartości moralne pokrywa się aksjologicznie z porządkiem moralnym lub harmonizuje z nim.

Kelsen odrzuca jednak takie rozumowanie na rzecz twierdzenia, że między moralnymi wartościami a treścią normy prawnej nie występują żadne konieczne powiązania. Przyjęcie, że normy moralne realizowane są przez prawo pociągałoby bowiem za sobą konieczność pomyślenia jakiegoś uniwersum moralnego, w którym należy wyróżnić te wartości, które powinny być normatywizowane i postrzegane jako prawo. Innymi słowy, koncepcja ta implikuje zasadność absolutnej moralności poprzez uznanie absolutnych wartości moralnych identyfikowanych z normami prawnymi (Stewart 1990, 4). Autor zaznacza, że prawo może być usprawiedliwiane moralnością jedynie

18 Kelsen podkreśla, że pojęcie moralności w kontekście prawnym jest bardzo często utożsamiane z pojęciem sprawiedliwości. 
wtedy, gdy treść norm prawa nie odpowiada treści norm moralnych; a to wbrew pozorom dość częsty przypadek w pluralistycznym społeczeństwie.

\subsection{Legitymizacja moralna dla prawa}

Fakt, że między normami prawa a normami moralności może istnieć dysonans oznacza, że prawo i moralność są różnymi od siebie porządkami. Co więcej, rozdział przeprowadzany między etyką i prawoznawstwem daje podstawy by sądzić, że prawo nie wymaga moralnej legitymizacji - a przynajmniej nie na poziomie jednej, określonej moralności. Być może jednak podlega moralnej ocenie ze strony tzw. społecznej moralności krytycznej w rozumieniu Harta. Do zadań metody badawczej nauk prawnych nie należy bowiem ocenianie norm, lecz ich poznanie i opisanie. Pomimo, iż normy prawne, rozumiane jako usankcjonowane powinności, stanowią swoiste wartości, to utożsamianie prawoznawstwa z aksjologią wydaje się niedorzecznością (Kelsen 1970, 67). Wartość prawa nie wynika bowiem z jego treści, lecz z formy, co wykazano już wyżej. Innymi słowy, jeśli możliwa jest sprzeczność między normami prawnymi a normami moralnymi. Ponadto, jeśli normy te obowiązują na gruncie swoich porządków, to według Kelsena powstaje wymóg rozdziału etyki od nauk prawnych.

Tym bardziej zasadne wydaje się roszczenie Kelsena do relatywizmu moralnego. Należy bowiem uświadomić sobie swoistą dysproporcję między prawem a etyką: polega ona choćby na tym, że danej normie prawnej może odpowiadać kilka norm z zakresu różnych porządków moralnych, podczas gdy innej normie prawnej nie odpowiada żadna norma wyrażająca zasadę moralną. Okazuje się bowiem, że spektrum powinności jest na tyle szerokie, iż nie każda norma jednego porządku musi być sprzężona $\mathrm{z}$ normą innego porządku. A zatem etyczne ukontekstowienie normy prawnej jest tyleż możliwe, co niekonieczne (Hart 1958, 604-605). Można bowiem pomyśleć sobie sytuację, w której stworzony zostaje dany porządek prawny, mający ścisły związek $\mathrm{z}$ porządkiem moralnym. Jednakże na gruncie przemian społecznych lub ekonomicznych, porządek moralny ewoluuje tak długo, aż na zrębach poprzedniego powstanie nowy, całkowicie różny od poprzedniego porządek moralny. Owa zmiana etycznego paradygmatu nie musi jednak implikować zmiany porządku prawnego, choć mogę one ze sobą korelować lub harmonizować, jak podkreśla np. Jon Elster. Co więcej, pewne normy prawne, dotychczas pozostające w zgodzie z normami moralnymi, okazują się być sprzeczne z nowo powstałymi wartościami. Nie znaczy to jednak, że prawo jest pozbawione wartości ${ }^{19}$ i przestaje obowiązywać. Wręcz przeciwnie; uzmysławia to, że $\mathrm{w}$ ramach jednego społeczeństwa może istnieć wiele porządków moralnych, podczas gdy regulatywną podstawą zachowania pozostaje norma prawna.

19 Jak zostało już wcześniej wykazane - prawo zawsze (na mocy własnej struktury) ma wartość prawną, a etyczność i sprawiedliwość nie gwarantują jego obowiązywalności. 
Innymi słowy, powszechna w okresie XIX i XX-wiecznego przesilenia pozytywistycznego teza głosząca, że prawo musi być w swej naturze moralne, a niemoralne (niesprawiedliwe) prawo traci lub nie może uzyskać statusu prawa jest wynikiem uznania absolutnej teorii wartości. Jednak Kelsen odrzuca ją także $\mathrm{z}$ innego powodu; prowadzi ona bowiem do nadania prawu bezkrytycznej lub arbitralnej legitymizacji, co znaczy, że jej stosowanie prowadzi do ukonstytuowania państwowych instytucji na gruncie innym aniżeli prawny.

Z szeroko rozumianej czystej teorii prawa wynika, że prawo, którego elementem konstytutywnym są także instytucje, może uzyskać legitymizację wyłącznie na mocy twierdzeń z zakresu nauk o prawie. Znaczyłoby to, że poszukiwanie źródeł obowiązywalności prawa także poprzez państwowe instytucje lub w innych naukach pozbawia je autonomicznej wartości prawnej, przez co nie może ono spełniać swojej nadrzędnej roli, jaką jest publiczna służba społeczna. Zatem uzasadnianie prawa pozytywnego przez moralność jest możliwe wyłącznie dzięki temu, że między prawem i moralnością zachodzi kontrast. Innymi słowy, prawo może być moralnie złe lub dobre (Kelsen 1970, 68-69), jednak taka ewaluacja porządku prawnego jest z perspektywy czystej teorii prawa jako nauki, której zadaniem jest poznanie swojego przedmiotu takim, jakim ono jest, całkowicie indyferentna.

\subsection{Ku koncepcji prawa amoralnego}

Kelsen dokonuje odseparowania prawa od wszystkich obcych elementów. Jest to jedyna metoda zapewnienia czystości jego teorii. Oznacza to także, na poziomie teoretycznym, odseparowanie formy normy prawnej od jej treści. Uważa on bowiem, że naukowa analiza czystej teorii prawa nie może być zaciemniana przez żadne zewnętrzne czynniki, natomiast treść norm prawnych może być bardzo łatwo mylona $\mathrm{z}$ treścią norm etycznych. Zatem prawo, z perspektywy swojej własnej struktury, musi być amoralne, czyli nie może być reprezentatywne dla żadnej i niczyjej moralności i na odwrót, żadna i niczyja moralność nie być reprezentatywna dla prawa.

Normy prawne wyrażają powinności, jednak są one inne niż powinności wynikające $\mathrm{z}$ wartości (oughts of value). Te pierwsze kształtują zatem formę normy - dyspozycję i sankcję, podczas gdy te drugie warunkują treściową zawartość normy. Z punktu widzenia Kelsenowskiej teorii moralność jest sprowadzalna do systemu ocennego zachowań i powinności, co determinuje jej subiektywną naturę. Nie można jej zatem wcielić do nauki o prawie, traktującej o swoim przedmiocie jako obiektywnym fenomenie (White 1996, 235).

Teoria Kelsena czerpie więc w swojej strukturze, podstawowych podziałach i metodologicznym podłożu z dorobku kantyzmu. Kantyzm wyróżnia w zasadzie trzy płaszczyzny racjonalności - teoretyczną, zainteresowaną poznaniem i opisaniem rzeczywistości, będącą funkcją myślenia, odniesioną do sfery bytu oraz praktyczną, zainteresowaną 
obowiązkiem i zobowiązaniem, będącą funkcją woli, którą należy postrzegać jako Kelsenowską sferę powinności. Trzecia funkcja racjonalności to sądzenie, którego tutaj nie rozpatrujemy. Jednak w gruncie rzeczy Kelsen odrzuca koncepcję rozumu praktycznego - lecz nie dlatego, że myli się uważając, że istnieją dwa osobne rozumy, czysto teoretyczny i praktyczny (Kant przyjmuje jedną instancję jednego rozumu, w funkcji zarówno czysto refleksyjnej jak i praktyczno-prawodawczej, a ponadto - w funkcji sądzenia), lecz dlatego, że różnica między sferą bytu i powinności nie jest pochodzą „różnych rozumów”, lecz wypływa $\mathrm{z}$ wewnętrznego, kognitywno-afektywnego zróżnicowania funkcji umysłu. To właśnie afektywność (mylnie sprowadzana do emotywizmu) jest napędem powstawania sądów ocennych, którymi posiłkuje się moralność (Paulson 1992, 10), zmuszona jednak artykułować, uzasadniać lub racjonalizować swoje twierdzenia. Jeśli zatem nie można jej wywieść $\mathrm{z}$ „czystego” rozumu, to może być ona kwalifikowana wspólnie z porządkiem prawnym, w obrębie tych samych norm. Ponadto, moralność stanowi dla Kelsena przedmiot osobistych, subiektywnych preferencji, które nie mogą być ujmowane w ramy obiektywnych opisów rzeczywistości powinności 20 . Punktem wyjścia dla Kelsena jest zatem kantowskie z ducha założenie, że nauka o powinnościach jest obiektywnym światem, przetworzonym przez rozum na konkretne kategorie, aplikowane $\mathrm{w}$ racjonalnym poznaniu i determinującym zarówno orientację poznawczą, jak i modus poznania normatywnego. Zatem przedmiot poznania nie przejawia mu się bezpośrednio, lecz za pomocą odpowiednich, wytworzonych w tym celu, racjonalnych kategorii. Na tej epistemologicznej podstawie rozwija Kelsen ontologiczne ujęcie powinności, w którym opis norm nie jest w żadnym wypadku zależny od jakiegokolwiek i czyjegokolwiek standardu ewaluacji. Zatem brak norm moralnych jako komponentów porządku prawnego jest z jednej strony logiczną konsekwencją, a z drugiej - dowodem na skuteczność tezy o separacji prawa i moralności (Cohen 1978, 9).

Podsumowując rozważania przedstawione powyżej można stwierdzić, że jedną z naczelnych zasad konstrukcyjnych czystej teorii prawa jest zasada, wedle której porządek prawny ma zdolność do nadawania sobie samemu kształtu. Normy zyskują ważność poprzez wynikanie normy indywidualnej z generalnej, tworząc tym samym niesprzeczną całość. Uznanie ważności jednej z norm przebiega wewnątrzsystemowo, tj. immanentnie dla systemu (ważność normy niższej warunkowana jest ważnością normy wyższej), co zapewnia konstrukcji skuteczność tak długo, dopóki normy - rozumiane jako całość systemu - będą uznawane za skuteczne (White 1996, 237). Teoretyczna autonomia prawa jest zatem zapewniona dopóty, aż normy zostaną pozbawione treści. Jednakże zmiana statusu ontologicznego normy nie wpływa na

20 Nie wpływa to jednak na ich roszczenia do normatywizacji przedmiotu, który bada etyka. 
zasadność jej legitymizacji; daje jedynie szerokie pole do interpretacji, których osądy nie będą już stanowiły prawa w rozumieniu czystej teorii.

\section{Literatura}

Anderson, S. 2010. The Enforcement Approach to Coercion. Journal of Ethics and Social Philosophy Vol. 5 No 1: 1-31.

Brożek, A., Brożek, B., Stelmach, J. 2013. Fenomen normatywności. Kraków: Copernicus Center Press.

Cohen, J. 1978. The Political Element in Legal Theory: A Look at Kelsen`s Pure Theory. Yale Law Journal Vol. 88 No 1: 1-38.

Edel, A. 1970. On Certain Value-Dimension in Analysis of Moral Relativism. The Journal of Philosophy Vol. 67 No 17: 584-588.

Gardner, J. Legal Positivism: 5 1/2 Myths. American Journal of Jurisprudence Vol. 46 No 1: 199-227.

Green, M. S. 2003. Hans Kelsen and the Logic of Legal Systems. Alabama Law Review Vol. 53 No 2: 365-413.

Guyer, P. 2010. Moral Feelings in the 'Metaphysics of Morals'. W: Denis, L. (ed.) Kant's Metaphysics of Morals: A Critical Guide. Cambridge: Cambridge University Press.

Halpin, A. 2006. Ideology and Law. Journal of Political Ideologies Vol. 11, No 2: 153-168.

Harman, G. 1975. Moral Relativism Defended. The Philosophical Review Vol. 84, No1: 35-43.

Hart, H. L. A. 1958. Positivism and the Separation of Law and Morals. Harvard Law Review Vol. 71 No 4: 593-629.

Jelić, Z. 2001. An Observation on the Theory of Law of Hans Kelsen. Law and Politics Vol. 1 No 5: 551-570.

Kant, I. 2009. Uzasadnienie metafizyki moralności. Przeł. M. Wartenberg. Kęty: Wydawnictwo Marek Derewiecki.

Kelsen, H. 1970. Pure Theory of Law. Berkeley/Los Angeles: University of California Press.

Moser, S. 1979. Ethical Non-Cognitivism and Kelsen's Pure Theory of Law. The University of Toronto Law Journal Vol. 29 No 2: 93-113.

Patterson, E. W. 1952. Hans Kelsen and His Pure Theory of Law. California Law Review, Vol. 40, No 1: 5-13.

Paulson, S. L. 1992. Introduction. In: Kelsen, H. Introduction to the Problems of Legal Theory. Przeł. Paulson, B. L., Paulson, S. L. Oxford: Clarendon Press.

Radbruch, G. 2009. Filozofia prawa. Tłum. E. Nowak. Warszawa: PWN.

Smith, M. 2003. Neutral and Relative Value After Moore. Ethics, Vol. 113, No 3: 576-598.

Stewart, I. 1990. The Critical Legal Science of Hans Kelsen. Journal of Law and Society Vol. 17 No 3: 273-308. 
Tokarczyk, R. 2009. Filozofia prawa.Warszawa: Lexis Nexis.

Vinx, L. 2007. Hans Kelsen's Pure Theory of Law: Legality and Legitimacy. Oxford: Oxford University Press.

White, B. 1996. Is There a Place for Morality in Law?. QUT Law Journal, Vol. 15: 229-242.

Wróblewski, J. 1955. Krytyka normatywistycznej teorii prawa i państwa Hansa Kelsena. Warszawa: PWN.

Zalewska, M. 2011. Historia pewnego przypisu. Próba rekonstrukcji dyskusji Hansa Kelsena z Jerzym Wróblewskim. Archiwum Filozofii Prawa i Filozofii Społecznej UŁ Vol. 1: 75-85.

Zalewska, M. 2014. Problem zarachowania w normatywizmie Hansa Kelsena. Łódź: Wydawnictwo Uniwersytetu Łódzkiego.

Zirk-Sadowski, M. 2009. Soft-Kelsenism versus Multicentrism. W: ZirkSadowski, M. Golecki, M., Wojciechowski, B. (eds.) Multicentrism as an Emerging Paradigm in Legal Theory. New York: Peter Lang. 
Marta Huk (Adam Mickiewicz University)

\title{
o separacji między prawem i moralnością. Glosa do Czystej teorii prawa Hansa Kelsena
}

\begin{abstract}
This paper is dedicated to the problem of separation legal and moral order from the perspective of Kelsen`s Pure Theory of Law. In discussing the need for such a separation, the author shows its relevant consequences. According to the most controversial of them, the "amoral law" seems to be a very sovereign normative concept. But still another question arises - would legal subjects be able to cooperate with the law when its effectiveness is only based on the coercive power and sanctions?
\end{abstract}

Keywords: norm, legal order, moral order, separation thesis, amoral law Ethics in Progress (ISSN 2084-9257). Vol. 4 (2013). No. 2, pp. 113-136. 